\title{
Analisis Efisiensi Kompor Menggunakan Bahan Bakar Pertalite
}

\author{
Vahrullah Mokoagow $^{1)}$, Romi Djafar ${ }^{2)}$, Sjahril Botutihe ${ }^{3)}$ \\ 1,2,3) Program Studi Mesin dan Peralatan Pertanian, Politeknik Gorontalo, Jl. Muchlis Rahim, Desa Panggulo \\ Barat, Kec. Botupingge, Kab. Bone Bolango, Gorontalo, Indonesia \\ e-mail: vahrullah27@gmail.com
}

\begin{abstract}
ABSTRAK
Bahan bakar minyak seperti pertalite umumnya hanya digunakan sebagai bahan bakar kendaraan bermotor. Di sisi lain, gas digunakan sebagai bahan bakar kompor untuk memasak. Disamping kesediaannya yang terbatas, harganya pun lebih mahal dibandingkan dengan bahan bakar cair. Oleh karena itu, perlu adanya alat alternatif kompor yang menggunakan bahan bakar selain gas seperti bahan bakar pertalite. Untuk mengetahui pemanfaatan pertalite sebagai bahan bakar kompor pengganti gas maka perlu dilakukan penelitian. Adapun tujua penelitian ini adalah untuk mengetahui efek kompor pertalite terhadap pendidihan air, pengaruh tekanan kompresor terhadap nyala api yang dihasilkan, dan mengetahui performa kompor berbahan bakar pertalite. Penelitian ini dilakukan dengan metode Water Boiling Test (WBT) melalui tiga tahapan. Pertama, uji WBT kompor dengan volume bahan bakar yang sama dengan volume air yang berbeda sehingga diketahui lamanya waktu pendidihan. Tahapan kedua, yaitu melakukan uji WBT dengan mengukur jumlah maksimal air yang dapat dipanaskan pada jumlah bahan bakar tertentu. Tahapan ketiga, yaitu melakukan uji WBT dengan jumlah air 1000 ml dengan waktu pendidihan pada penambahan tekanan udara pada kompor sebesar 1 atm (tekanan normal), 0,2 bar, dan 0,5 bar untuk menentukan besar energi kalor yang dihasilkan serta efisiensi kompor yang dihasilkan.

Berdasarkan hasil penelitian diketahui bahwa lamanya waktu pendidihan berbading lurus dengan volume air yang dididihkan. Semakin banyak volume air maka diperlukan waktu pendidihan yang semakin lama. Demikian juga dengan kosumsi bahan bakar pertalite. Volume air yang dididihkan semakin banyak maka dibutuhkan bahan bakar pertalite yang semakin banyak. Selain itu, energi kalor terbesar kompor alternatif berbahan bakar pertalite diperoleh pada penambahan tekanan sebesar 0,5 bar yakni sebesar 2,695 kal/detik, namun efisiensi terbesar didapat pada penambahan tekanan sebesar 0,2 bar dengan besaran efisiensi $24,734 \%$.
\end{abstract}

Kata Kunci: kompor alternatif, pertalite, energi kalor, efisiensi

\begin{abstract}
Fuel oil such as pertalite is generally only used as motor vehicle fuel. On the other hand, gas is used as stove fuel for cooking. Besides its limited availability, the price is also more expensive than liquid fuel. Therefore, there is a need for alternative stoves that use fuels other than gas such as pertalite fuel. To find out the use of pertalite as a fuel for gas stoves, it is necessary to do research. The purpose of this study was to determine the effect of the pertalite stove on boiling water, the effect of compressor pressure on the resulting flame, and to determine the performance of the pertalite-fueled stove. This research was conducted using the Water Boiling Test (WBT) method through three stages. First, test the WBT of the stove with the same volume of fuel with different volumes of water so that the boiling time is known. The second stage is to conduct a WBT test by measuring the maximum amount of water that can be heated in a certain amount of fuel. The third step is to do a WBT test with $1000 \mathrm{ml}$ of water with a boiling time on the addition of 1 atm air pressure (normal pressure), 0.2 bar, and 0.5 bar to determine the amount of heat energy produced and the efficiency of the stove.

Based on the results of the study, it is known that the length of the boiling time is directly proportional to the volume of boiling water. The greater the volume of water, the longer it takes to boil. Likewise with pertalite fuel consumption. The more the volume of boiling water, the more pertalite fuel is needed. In addition, the greatest heat energy for the alternative stove with pertalite fuel is obtained at an additional pressure of $0.5 \mathrm{bar}$, which is $2.695 \mathrm{cal} / \mathrm{second}$, but the greatest efficiency is obtained at an additional pressure of 0.2 bar with an efficiency of $24.734 \%$.
\end{abstract}

Keywords: alternative stove, pertalite, heat energy, efficiency 


\section{PENDAHULUAN}

Kompor adalah alat masak yang menghasilkan panas tinggi. Kompor mempunyai ruang tertutup atau terisolasi dari luar sebagai tempat bahan bakar diproses untuk memberikan pemanasan bagi barangbarang yang diletakkan di atasnya. Kompor diper kenalkan sejak masa kolonial, sehingga menggunakan bahan bakar cair terutama minyak tanah atau spiritus bakar, gas dalam bentuk padatan cair LPG atau lewat pipa saluran, atau elemen pemanas dengan daya listrik. Alat pemanas dengan fungsi serupa kompor tetapi menggunakan bahan bakar padat seperti arang atau batu bara dengan ruang pemanas terbuka di Indonesia. Saat ini berbagai keluhan yang dihadapi ibu-ibu rumah tangga seperti harga gas yang tinggi jika ketersediaannya sangat langka. Sehingga dapat dicari alat alternatif kompor yang menggunakan bahan bakar selisih gas seperti bahan bakar pertalite.

Dengan bahan bakar minyak tanah pertalite diperkenalkan pertama kali oleh Alexis Soyer yang bertekanan udara yang dicampur minyak tanah, sementara kompor gas yang tidak memiliki tekanan dan memakai sumbu kompor tidak bias diketahui dengan pasti waktu penemuannya. Kemudian tahun 1820, merupakan tahun ditemukan kompor yang masih bersifat eksperimen dan rahasia. Selanjutnya pada tahun 1880, kompor ini mulai berkembang secara komersial meski masih terhambat karena jaringan pipa gas yang tumbuh dengan lambat. Terakhir di tahun 1960-an telah dilakukan pembuatan kompor yang menggunakan bahan bakar minyak tanah tanpa sumbu. Namun, pembuatan kompor itu terhenti dan banyak masalah dalam pembuatan sehingga diperlukan rancangan yang berkesinambungan.

Bendasarkan uraian di atas maka perlu adanya kompor berbahan bakar alternatif dari pertalite yang sumbunya mudah diperoleh d ikalangan masyarakat. Adapun tujua penelitian ini adalah untuk mengetahui efek kompor pertalite terhadap pendidihan air, pengaruh tekanan kompresor terhadap nyala api yang dihasilkan, dan mengetahui performa kompor berbahan bakar pertalite.

\section{METODE PENELITIAN}

\section{Waktu dan Tempat}

Penelitian ini akan dilakukan pada bulan April - Juni 2020. Tempat penelitian akan dilakukan di lab. Mesin Umum Politeknik Gorontalo. Adapun untuk proses desain alat, frabikasi, dan pengujian fungsional dilakukan di Lab. Mesin Umum, Program Studi Mesin dan Peralatan Pertanian Politeknik Gorontalo.

\section{Diagram Alir}

Diagram alir penelitian dapat dilihat pada Gambar 1.

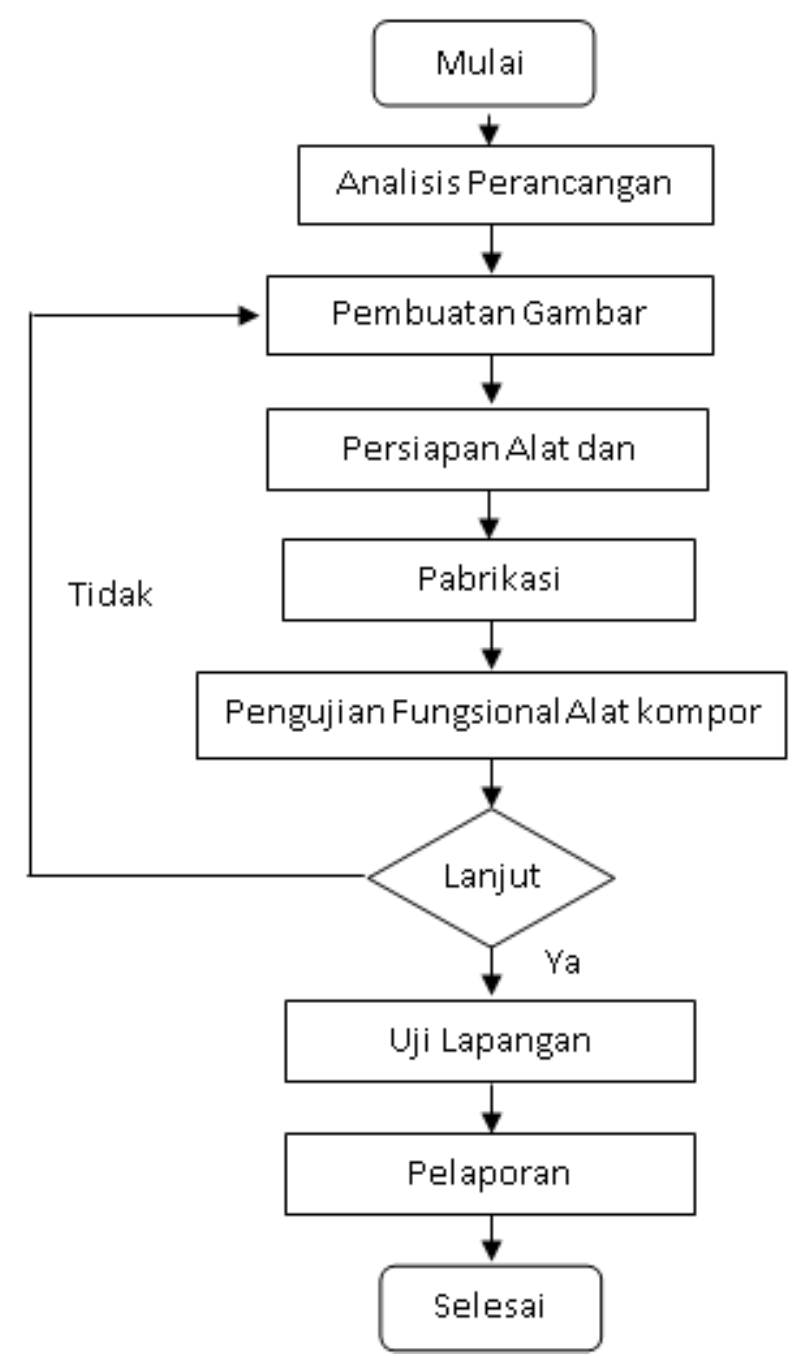

Gambar 1. Diagram Alir Penelitian

\begin{abstract}
Alat dan Bahan
Beberapa alat dan bahan yang digunakan antara lain kamera, komputer, software, mesin las, mesin frais, mesin gurinda duduk, mesin gurinda tangan, meteran, jangka sorong, bor tangan, selang, pipa galvanis, mata bor, mata gurinda potong, electrode $\emptyset 1.6 \mathrm{~mm}$, kompresor listrik, air dan bahan bakar pertalite.
\end{abstract}




\section{Perancangan Alat}

Desain alat kompor alternatif menggunakan bahan bakar pertalite dapat dilihat pada Gambar 2 . Alat ini terdiri dari beberapa komponen dengan fungsi utamanya disajikan pada Tabel 1 .

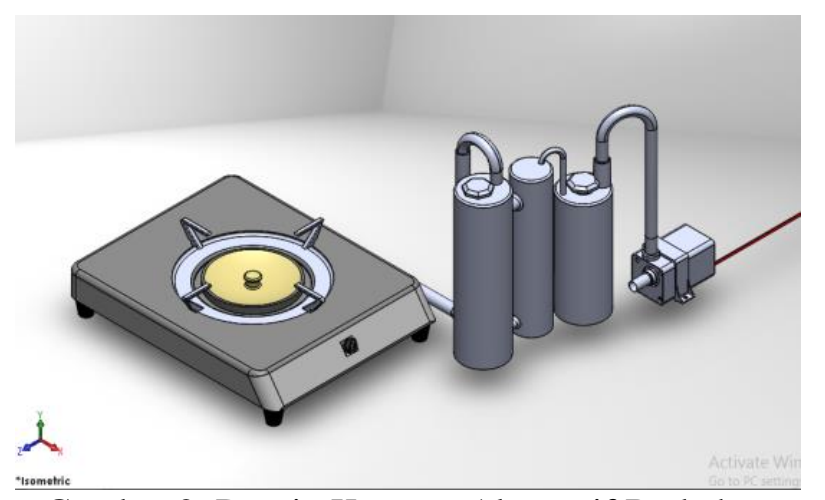

Gambar 2. Desain Kompor Alternatif Berbahan Bakar Pertalite

Tabel 1. Komponen-komponen Kompor dan Fungsinya

\begin{tabular}{|c|l|l|}
\hline No & Komponen & \multicolumn{1}{|c|}{ Fungsi } \\
\hline 1 & Pertalite & Sebagai bahan bakar \\
\hline & Tabung & $\begin{array}{l}\text { Sebagai tempat pertalite } \\
\text { dan udara }\end{array}$ \\
\hline & Pipa galvanis & $\begin{array}{l}\text { Penghubung antara tabung } \\
\text { instalasi air, udara, dan } \\
\text { pertalite }\end{array}$ \\
\hline & $\begin{array}{l}\text { Tungku } \\
\text { kompor }\end{array}$ & Penyangga alat masak \\
\hline
\end{tabular}

\section{Prosedur Pengambilan dan Analisis Data}

a. Pengujian fungsional

Pegujian ini bertujuan untuk mengetahui kinerja masing-masing komponen alat dalam perancangan fungsional meliputi kinerja kompor, kualitas nyala api, dan pegujian pendidihan.

b. Kualitas nyala api.

Kualitas nyala api diketahui melalui pengujian kompor dengan variasi volume bahan bakar dan tekanan. Variasi bertujuan untuk mencari nyala api yang baik dan tidak menimbulkan asap hitam serta waktu pembakaran lebih efisien. Suhu api akan diukur dengan menggunakan termometer.

\section{Prosedur Pengujian}

1. Mempersiapkan alat dan bahan yang digunakan yaitu:

- Gelas ukur

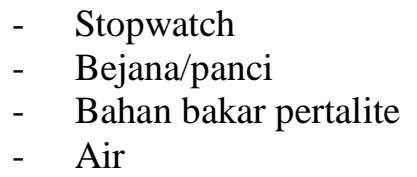

2. Memasang selang dari tabung bahan bakar ke kompor

3. Memastikan apakah setelah pemasangan selang tidak ada yang bocor, jika tidak ada maka dilakukan tahapan yang berikutnya.

4. Menyalakan kompor menggunakan pemantik dari korek api

5. Menentukan suhu panas yang akan digunakan untuk mendidihkan air kemudian dilakukan pengujian dengan 3 kali pengujian.

6. Pengujian dilakukan dengan variasi volume air masing-masing $500 \mathrm{ml}, 1000 \mathrm{ml}$ dan $1500 \mathrm{ml}$.

7. Menghitung berapa waktu yang diperlukan untuk mendidihkan air sebanyak 500 ml, 1000 $\mathrm{ml}$ dan $1500 \mathrm{ml}$.

\section{HASIL DAN PEMBAHASAN}

\section{Hubungan Nyala Api Kompor Pertalite terhadap Pendidihan Air}

Hasil pengujian lamanya waktu pendidihan untuk volume air yang berbeda dapat dilihat pada Gambar 3.

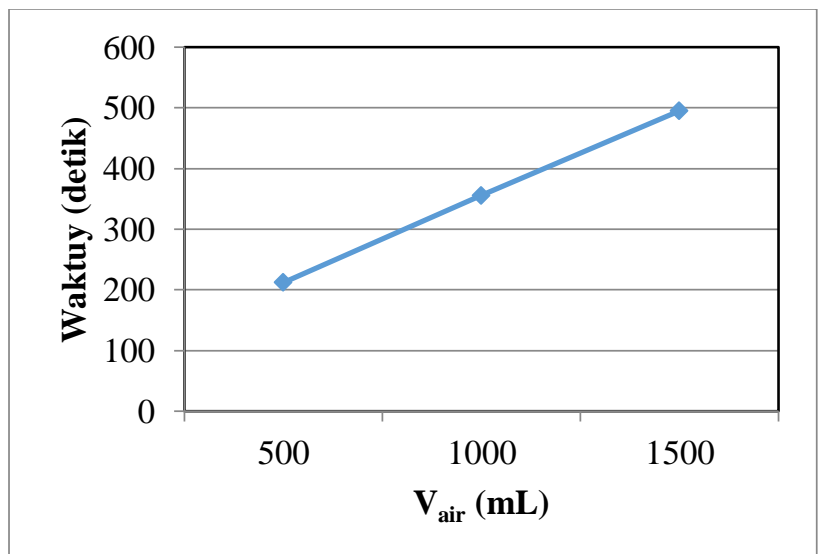

Gambar 3. Hubungan Volume Air dengan Lamanya Pendidihan

Berdasarkan Gambar 3 diketahui bahwa untuk mendidihkan air sebanyak 500, 1000, dan $1500 \mathrm{ml}$ diperlukan waktu masing-masing selama 212, 356, dan 495 detik. Hal ini mengindikasikan bahwa semakin banyak volume air yang dididihkan maka semakin semakin lama waktu yang diperlukan untuk mendidihka. Artinya, semakin banyak jumlah kalor yang perlukan dimana kalor berbanding lurus dengan massa bahan yang dipanaskan, $\mathrm{Q}=\mathrm{m} \times \mathrm{C}$ x $\Delta T$ (Roy, Hudoyo 2013). Semakin banyak kalor yag 
diperlukan berimplikasi pada penggunaan bahan bakar yang semakin meningkat (Gambar 4).

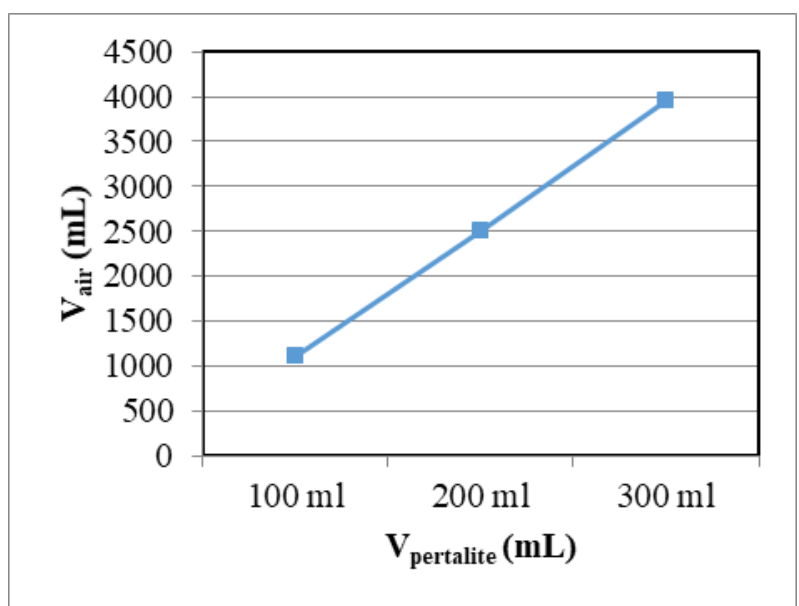

Gambar 4. Grafik Pendidihan

Gambar 4 menunjukkan kemampuan dari bahan bakar pertalite dalam mendidihkan air. Penggunaan pertalite sebanyak $100 \mathrm{~mL}$ mampu mendidihkan air sebayak $1100 \mathrm{~mL}$. Demikian juga pertalite $200 \mathrm{~mL}$ dan $300 \mathrm{~mL}$ masing-masing mampu mendididihkan air sebanyak $2500 \mathrm{~mL}$ dan $3950 \mathrm{~mL}$.

\section{Pengaruh Tekanan Kompresor Terhadap Nyala Api}

Penambahan tekanan pada pengujian bahan bakar pertalite mampu megubah warna nyala api dari merah kekuningan menjadi berwarna biru. Visualisasi dari nyala api yang dihasilkan sebagai akibat dari penambahan tekanan dapat dilihat pada Gambar 5.

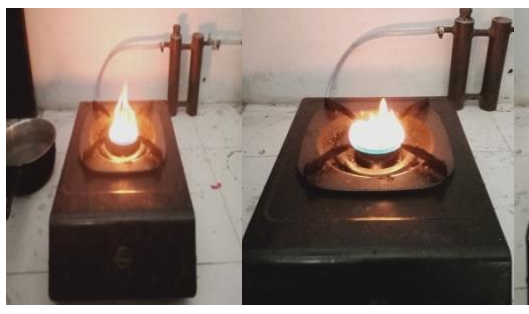

(a) (b)

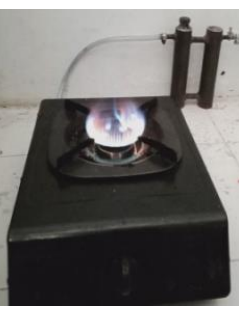

(c)
Gambar 5. Titik nyala api dengan Variasi Tekanan: (a) $1 \mathrm{~atm}$; (b) 0,2 bar; dan (c) 0,5 bar.

Pada tekanan normal, nyala api yang dihasilkan berwarna merah kekuningan mengindikasikan bahwa api yang dihasilkan hanya memiliki nilai kalor yang rendah sebagai akibat dari kurangnya suplai oksigen kedalam api tersebut. Pada penambahan tekanan, warna api menjadi biru mengindikasikan nilai kalor dari api yang dihasilkan tinggi, yang disebabkan karena oksigen telah ditambahkan kedalam api tersebut dengan media kompresor udara (Djafar, 2018). Peningkatan nilai kalor dari api akibat dari peningkatan jumlah oksigen sejalan pengertian umum dari proses pembakaran yaitu suatu runutan reaksi kimia antara suatu bahan bakar dan suatu oksidan, disertai dengan produksi panas yang kadang disertai cahaya dalam bentuk pendar atau api (wikipedia.org).

\section{Pengaruh Tekanan terhadap Suhu}

Pengaruh penambahan tekanan terhadap suhu dapat dilihat pada Gambar 6.

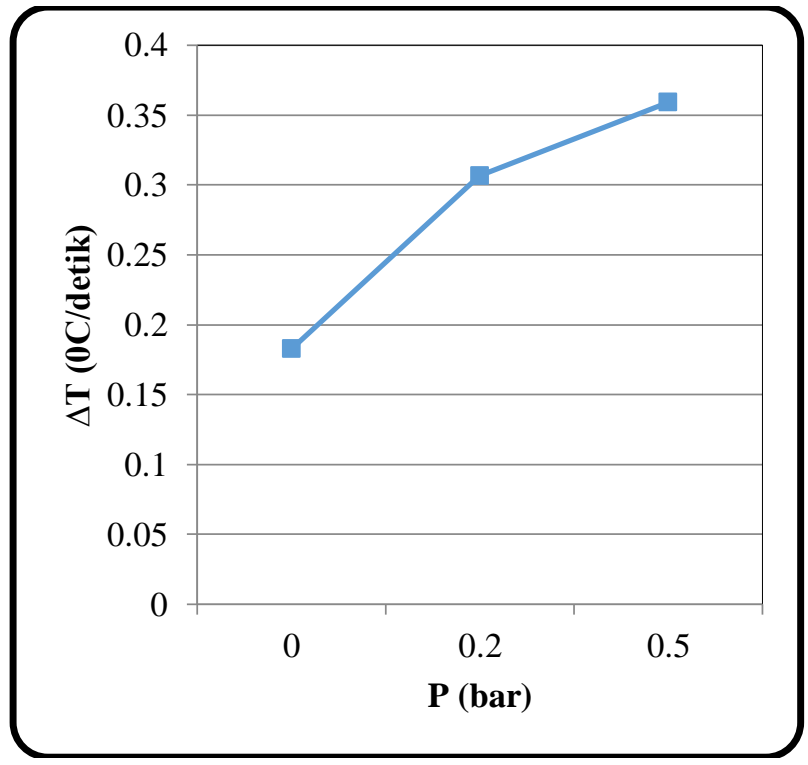

Gambar 6. Hubungan Tekanan terhadap Suhu

Gambar 6 menunjukkan bahwa penambahan tekanan dapat meningkatkan daya bakar dari pertalite itu sendiri. Hal ini dibuktikan dengan meningkatnya besaran kenaikan suhu perdetik sehingga waktu pendidihan akan semakin cepat sebagai akibat dari penambahan tekanan tersebut.

\section{Pengaruh Penambahan Tekanan Terhadap Laju Konsumsi Bahan Bakar}

Besaran laju konsumsi bahan bakar pertalite (Gambar 7) pada saat tidak ditambahkan tekanan udara padanya yaitu sebesar 18,8 ml/356 detik atau sebesar $0,053 \mathrm{ml} /$ detik. Namun apabila pada pertalite ditambahkan tekanan 0,2 bar, maka laju konsumsi bahan bakar sebesar34,7 ml/212 detik atau sebesar $0,164 \mathrm{ml} /$ detik dan apabila tekanan yang ditambahkan sebesar 0,5 bar, maka laju konsumsi pertalite menjadi sebesar $59,9 \mathrm{ml} / 181$ detik atau sebesar $0,330 \mathrm{ml} /$ detik. Nilai laju konsumsi bahan bakar (pertalite) ini diperoleh dengan membagi volume bahan bakar dalam hal ini pertalite dengan (penamba

han

tekanan 0,5 bar)
Mendidih sempurna 
lamanya waktu yang digunakan untuk mendidihkan sejumlah massa air (Ahmad Amri, 2019).

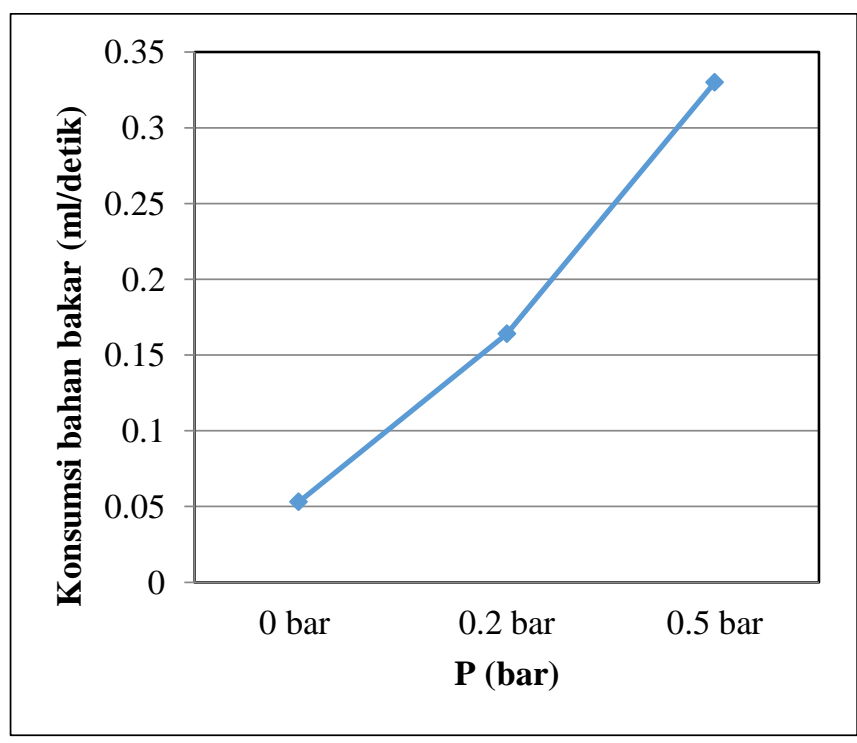

Gambar 7. Grafik Hubungan Tekanan terhadap Laju Konsumsi Pertalite

Gambar 7 menunjukkan bahwa konsumsi bahan bakar pertalite meningkat seiring dengan penambahan tekanan yang diberikan. Hal ini terjadi karena semakin banyak tekanan gas yang diberikan kepada pertalite itu sendiri, maka akan semakin banyak juga pertalite yang akan berubah fase dari fase cair (liquid) menjadi gas/menguap.

\section{Pengaruh Tekanan terhadap Energi Kalor}

Nilai energi kalor yang dihasilkan oleh suatu bahan bakar merupakan hasil perkalian dari para meter nilai kalor suatu bahan bakar dengan besarnya laju konsumsi bahan bakar yang terjadi (Ahmad Amri, 2019).

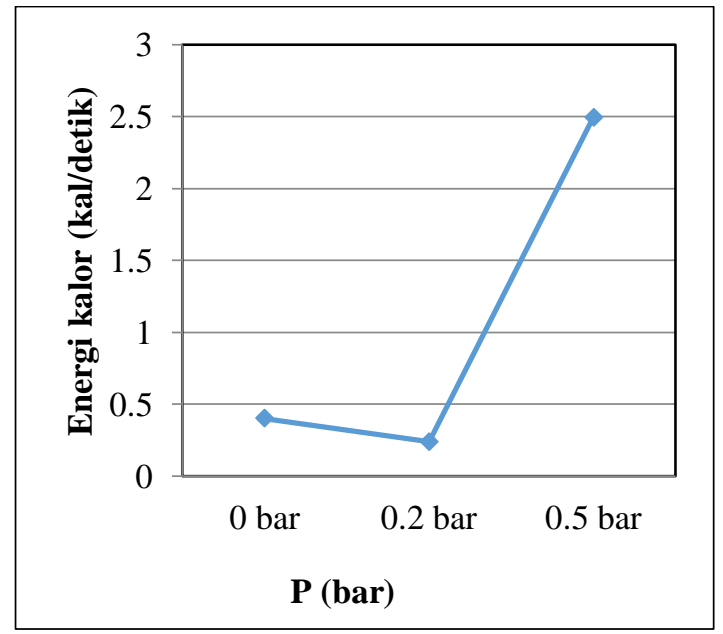

Gambar 8. Grafik Hubungan Tekanan terhadap Energi Kalor
Gambar 8 menunjukkan adanya fluktuasi terhadap nilai energi kalor yang dihasilkan pada setiap variasi penambahan tekanan dimana pada tekanan normal (0 bar), energy kalor yang dihasilkan sebesar 0,4006 Kkal/detik kemudian menurun menjadi 0,2395 Kkal/detik pada penambahan tekanan sebesar 0,2 bar, kemudian naik kembali menjadi sebesar 2,4943 kal/detik pada penambahan tekanan sebesar 0,5 bar.

Turunnya energi pada penambahan tekanan 0,2 bar ini terjadi disebabkan karena pada saat penambahan tekanan 0,2 bar jumlah partikel pertalite yang terbakar secara umum lebih banyak dari pada jumlah pertalite yang terbakar pada percobaan tanpa penambahan tekanan. Kenaikan nilai energy kalor yang dihasilkan pada saat penambahan tekanan udara sebesar 0,5 bar terjadi sehubung dengan berkurangnya waktu pendidihan. Dimana pada saat kompor alternative ini dituntut untuk bias melakukan proses pendidihan dengan waktu yang lebih cepat maka setiap partikel bahan bakar dari kompor itu sendiri (pertalite) akan mengalami kinerja yang lebih berat dari kondisi / perlakuan sebelumnya dalam hal ini dengan meningkatkan kemampuan bakarnya.

\section{Perhitungan Efisiensi Pertalite Menggunakan Evaporator Pertalite}

Penentuan nilai efisiensi pertalite ini di awali dengan melakukan estimasi terhadap kalor yang dibutuhkan selama proses pendidihan untuk kemudian membandingkan dengan nilai energy kalor yang dihasilkan per detik.

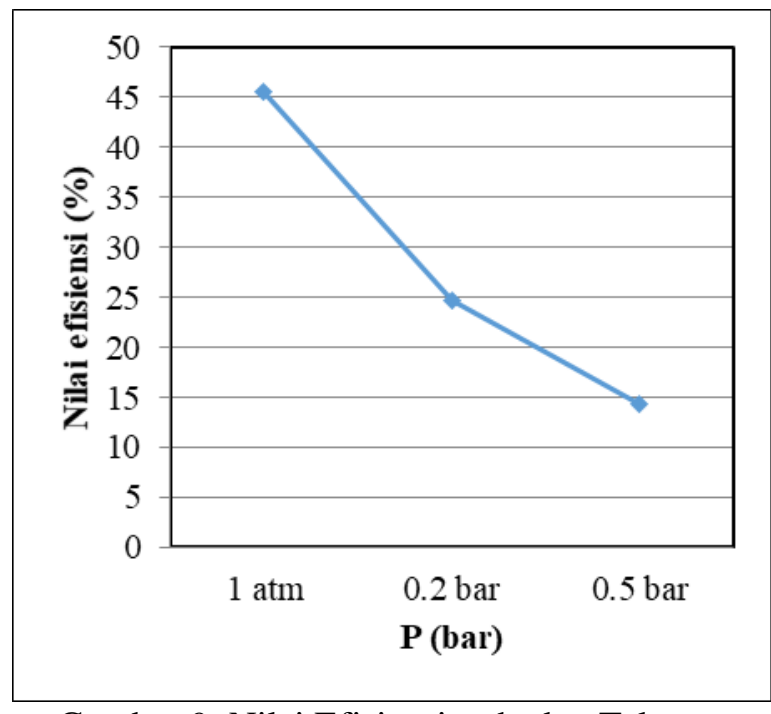

Gambar 9. Nilai Efisiensi terhadap Tekanan

Berdasarkan Gambar 9 disimpulkan bahwa efisiensi yang dihasilkan oleh pertalite apabila 
digunakan sebagai bahan bakar kompor alternative tanpa penambahan tekanan berkisar 45,5565\%, untuk penambahan tekanan sebesar 0,2 bar menurun menjadi $24,734 \%$, dan ketika tekanan ditambah, menjadi 0,5 bar, efisiensi berkurang, menjadi hanya berkisar $14,401 \%$.

Berdasarkan hal tersebut di atas, maka efisiensi pertalite dapat dikatakan menurun sejalan dengan penambahan tekanan yang diberikan. Hal utama yang mengakibatkan penurunan efisiensi ini yaitu adanya peningkatan nilai laju konsumsi bahan bakar yang signifikan pada penambahan tekanan, sementara di sisi lain laju konsumsi bahan bakar merupakan faktor pembagi pada formula untuk penentuan besarnya nilai efisiensi ini. Efisiensi yang terus mengalami penurunan apabila ditambahkan tekanan berarti bahwa penggunaan pertalite akan semakin boros bila tekanan yang diberikan padanya diperbesar.

\section{KESIMPULAN}

Berdasarkan uraian di atas dapat disimpulkan sebagai berikut:

1. Penambahan tekanan mempengaruhi nyala api yang dihasilkan kompor berbahan bakar pertalite, dimana semakin bertambah tekanan maka semakin biru nyala api pada kompor berbahan bakar pertalite.

2. Kompor berbahan bakar pertalite ini mampu memanaskan air sebanyak $1500 \mathrm{~mL}$ dalam waktu 8 menit 15 detik.

3. Apabila jumlah air yang dipanaskan menggunakan kompor berbahan bakar pertalite adalah sebanyak $1000 \mathrm{ml}$, dengan suhu awal $35^{\circ} \mathrm{C}$, maka dalam waktu 04 menit 49 detik, air sudah mencapai suhu $92^{\circ} \mathrm{C}$, dan dalam waktu 05 menit 56 detik air sudah mendidih sempurna dengans uhu $100^{\circ} \mathrm{C}$.

4. Energi kalor tertinggi yang dicapai dengan menggunakan kompresor pertalite yaitu pada saat dilakukan penambahan tekanan udara sebesar 0,5 bar, yakni sebesar 2,4943 kkal/detik, namun efisiensi tertinggi justru didapatkan pada saat tidak dilakukan penambahan tekanan udara, dengan nilai efisiensi sebesar $45,56 \%$.

\section{DAFTAR PUSTAKA}

Amri Ahmad, Hamri, Fikar Adriansyah Sofyan. 2016.Analisis Nilai Ekonomis Oli Bekas
Pada Kompor Bertekanan Berpemanas Awal. Universitas Muslim Indonesia.

Ariawan, I. W. B. (2016). Pengaruh Penggunaan Bahan Bakar Pertalite Terhadap Unjuk Kerja Daya, Torsi Dan Konsumsi Bahan Bakar Pada Sepeda Motor Bertransmisi Otomatis. 2(1), 5158.

Djafar, Romi. 2018. Pengaruh Jumlah Aliran Udara Terhadap Nyala Api Efektif Dari Reaktor Gas ifikasi Biomassa Tipe Fixed Bed Downdraft menggunakan Bahan Bakar Tongkol Jagung. JTech. Vol. 6 No.2 (2018) hal 94-100. Program Studi Mesin dan Peralatan Pertanian, Politeknik Gorontalo.

Gas, B. B. (2015). Peningkatan Efisiensi Kompor LPG Dengan Menggunakan Reflektor Radiasi Panas Bersirip (. 18(1), 94-105.

Hudoyo, Roy. 2013. Pengujian Pengaruh

Penambahan Material Pengotor Oli Bekas Jenuh Sebagai Identifikasi Kandungan Energi Pada Oli Murni. Fakultas Sains dan Matematika, Universitas Kristen Satya Wacana. Salatiga

Https://id.wikipedia.org/wiki/Pembakaran.

2018. Pembakaran. diakses pada 29 Juli 2020 pukul 17.14 WITA.

Https://www.otosip.com/2016 diakses pada 6 Agustus 2020 pukul 22.24 WITA.

Luthfi, M., Setiyo, M., \& Munahar, S. (2018).

Uji Komposisi Bahan Bakar dan Emisi Pembakaran Pertalite dan Premium. 10(1), 67-72.

Ningrat, A. A. W. K., Kusuma, I. G. B. W., \&

Wayan, I. (2016). Pengaruh Penggunaan

Bahan Bakar Pertalite Terhadap Akselerasi dan Emisi Gas Buang Pada Sepeda Motor Bertransmisi Otomatis. 2(1), 59-67.

Pangala, J. R., Tambunan, A. H., Kartodihardjo, H., \& Pari, G. (2016).Desain dan Pengujian Kinerja Kompor GasifikasiPirolisis. 6(1), 61-70.

Pratama, Hafiz M. 2016. Uji Eksperi mental Pengaruh Penambahan Bioetanol pada Bahan Bakar Pertalite Terhadap Unjuk 
Kerja Motor Bakar Bensin. Skripsi. Departemen Teknik Mesin Fakultas Teknik Universitas Sumatera Utara. Medan.

Puspitasari, D., Industri, D. T., Teknik, F., Utara, U. S., Engineering, K., Engineering, K., Fuels, A., Teknik, D., Fakultas, I., Universitas, T., Utara, S., Teknik, D., Fakultas, I., Universitas, T., \& Utara, S. (2014).Perancangan Kompor Sekam Padi Pada Industri. 5(1), 13-17.

Setiyo, M., Magelang, U. M., Munahar, S., \& Magelang, U. M. (2018).Uji komposisi bahan bakar dan emisi pembakaran pertalite dan premium .January. https://doi.org/10.24853/jurtek.10.1.67$\underline{72}$.

Widodo, A. S., Mesin, T., \& Brawi jaya, U. (2016). Peningkatan Efisiensi Sistem Pemanasan dengan Penambahan Grid pada Perforated.7(1), 21-25. 